\begin{tabular}{|c|c|c|c|}
\hline \multirow{2}{*}{$\begin{array}{c}\text { LARUS } \\
\text { Hrvatska akademija } \\
\text { znanosti i umjetnosti }\end{array}$} & 52 & $\begin{array}{c}35-48 \text { str. } \\
\text { 2 tablice, 7 slika }\end{array}$ & Zagreb 2017 \\
\cline { 2 - 4 } & \multicolumn{3}{|c|}{$\begin{array}{c}\text { Primljeno 30. 6. 2017. } \\
\text { Prihvaćeno na sjednici Razreda za prirodne znanosti HAZU 19.10.2017. }\end{array}$} \\
\hline
\end{tabular}

\title{
DISPERSAL OF THE WHITE STORK Ciconia ciconia IN THE LONJSKO POLJE NATURE PARK, CROATIA
}

\author{
Disperzija bijele rode Ciconia ciconia u Parku prirode Lonjsko polje, \\ Hrvatska
}

\section{Biljana JeČmenica ${ }^{1}$, Jelena Kralj ${ }^{2}$}

${ }^{1}$ Association BIOM, Preradovićeva 34, HR-10000 Zagreb, CROATIA ${ }^{2}$ Institute of Ornithology, Croatian Academy of Sciences and Arts, Gundulićeva 24, HR-10000 Zagreb, CROATIA

\begin{abstract}
There are two main types of dispersal: natal and reproductive. Natal dispersal is more common and individuals travel a greater distance than during reproductive dispersal. Direction and distances depend on various factors. Dispersal of the White Storks, Ciconia ciconia, was analysed using resightings of colour-ringed individuals in the Lonjsko polje Nature Park, Croatia. 36.7\% observed individuals did not disperse outside the natal settlement, while only $14.3 \%$ covered a distance longer than 50 $\mathrm{km}$. The median dispersal distance was $4.21 \mathrm{~km}(\mathrm{IQR}=0-8.8, \mathrm{n}=49)$; the correlation of dispersion with the number of nests in settlements and the size of the settlements was studied. Results have shown that storks are dispersing from settlements with a small number of nest to settlements with a large number of nests and that dispersal does not depend on the size of the settlement.
\end{abstract}

Keywords: White Stork Ciconia ciconia, dispersal distances, settlement size

\section{INTRODUCTION}

The term dispersion refers to undirected movement of individuals for seeking and occupying a habitat where they will be able to acquire life needs (GreEN-

e-mail: biljana.jecmenica@biom.hr; jkralj@hazu.hr 
wood 1980, Greenwood \& Harvey 1982). Berthold (2001) defines dispersal as a one-way movement of individuals in any direction where there is no exact pattern of movement as during migration. There are two main types of dispersal.

Natal dispersal is a movement of young individuals from the place where they are born to the place where they will start breeding (GreEnwood 1980, GreENwOOD \& HARVEy 1982). The distance that individuals pass during natal dispersal ranges from few to several hundred kilometres (PARAdis et al. 1998; Sutherland et al. 2000). Whether individuals will disperse or remain in their natal area depends on population density and distribution; quality and size of the habitat; individual dominance; sex; migration, and other biological and ecological features that have still not been fully clarified (Forero et al. 2002, Bowler \& BENTON 2005).

Reproductive dispersal is a movement between two sequential nesting attempts (Greenwood 1980, Greenwood \& Harvey 1982). Many species remain faithful to the breeding area or particular nest in the successive years. The advantage of using the same nest/nesting area is being familiar with the habitat within the breeding territory, which improves foraging efficiency and reduces predation. Furthermore, the known territory is easier to defend from other rivals (GreENwood 1980, Greenwood \& Harvey 1982, Paradis et al. 1998). Thereby, reproductive dispersal is not frequent and individuals do not travel long distances as in natal dispersion. Younger individuals much often undertake reproductive dispersal, because they have lower success in reproduction (GreEnwood \& HARver 1982).

Several studies have shown that reproductive dispersal in the White Stork Ciconia ciconia is very low and that birds that have successfully nested usually return to the same nest (BARBrAud et al. 1999, Vergara et al. 2006, ItonAGA 2009, Cuadrado et. al. 2016). However, dispersal of this species has not been studied in Croatia yet.

The White Stork is a common breeder in lowland areas of Croatia, with a total population estimated to 1100-1300 breeding pairs (KRALJ et al. 2013). They build nests singly or in loose colonies and can be regarded as a facultative colonial bird (Perennou et al. 1996). In Spain, as many as 9 nests have been found on one rooftop (CHOzAs 1984) and colonies may contain up to 30 pairs (GoRIUP \& SchUlz 1990). Out of the breeding season they are very social, spending time in flocks, especially during migration and wintering. Both parents build and maintain nests, incubate and bring food and water to the young (CRAmp \& Simmons 1977).

The Lonjsko polje Nature Park is located in the middle part of the Sava River, about $75 \mathrm{~km}$ to the southeast of Zagreb, the capital of Croatia. It covers natural alluvial wetlands, flooded pastures and oak forests on both sides of the Sava River. The total area covers $506.50 \mathrm{~km}^{2}$ (Gugrć et al. 2011). The ringing of stork nestlings with metal rings in the Nature Park started in 1983, while colour rings were introduced in 2002 (KRALJ et al. 2013); ringing has almost continuously been carried out since then. 
The aim of the research was: 1) to determine the level of natal dispersal by analysing resightings of the colour-ringed White Storks; 2) to find out if there is a relationship of natal dispersal and its direction to the size of the settlements and number of nests; and 3) to identify eventual reproductive dispersal in this species.

\section{MATERIAL AND METHODS}

Between 2002 and 2014, 1949 White Stork chicks were marked in the Lonjsko polje Nature Park (which makes $57.3 \%$ of all White Storks colour-ringed in that period) with individually recognisable yellow darvic rings with black inscriptions (four letters or digits). The data used in this research refer to the data collected during ringing and by accidental observations in the period from 2004 to 2014, obtained from the Archives of the Institute for Ornithology, Croatian Academy of Sciences and Arts, and the data collected during fieldwork in 2015. During the breeding season (June 2015), adult colour-ringed birds were observed in 11 settlements (out of 13 settlements where they breed) in the Lonjsko polje Nature Park: Osekovo, Stružec, Čigoć, Kratečko, Mužilovčica, Suvoj, Lonja, Puska, Krapje, Drenov Bok, and Jasenovac. Only two settlements with known stork nests were omitted (Mlaka and Košutarica - with 2 nests in total). Only observations of ringed birds in nest were considered. The location of each nest was recorded by GPS, and colour rings were read by a binocular Olympus DPS-I $8 \times 40$ and a telescope Celestron 20-60 $\times 80$. Since the exact GSP location of ringing was not recorded, birds found breeding in a settlement where they had hatched were considered to have not dispersed.

To analyse if there is dependence between natal dispersion and a number of nests per village, settlements were grouped according to the total number of active nests per settlement: primary (with $\geq 10$ nests) and secondary (less than 10 nests). For determining whether there is dependence between dispersion and size of the settlements, settlements were grouped according to the length: small (length $<3 \mathrm{~km}$ ) and large (length $\geq 3 \mathrm{~km}$ ). The size of the settlement was obtained by measuring the length of the street from the first to the last house using satellite images by Google maps. The length expressed in kilometres represents the size of the settlement and indicates the space available for nesting (Table 1). 
Table 1. Number of breeding pairs in 2015 and length of settlements (in $\mathrm{km}$ ).

Tablica 1. Broj gnjezdećih parova u 2015. god. i dužina naselja izražena $u \mathrm{~km}$.

\begin{tabular}{|c|c|c|}
\hline Settlement & $\begin{array}{l}\text { No. of nests } \\
\text { (in 2015) }\end{array}$ & $\begin{array}{c}\text { Length of settlement } \\
(\mathrm{km})\end{array}$ \\
\hline Čigoč & 32 & 1.90 \\
\hline Bobovac & 23 & 2.38 \\
\hline Osekovo & 20 & 4.91 \\
\hline Gušće & 19 & 5.21 \\
\hline Mužilovčica & 15 & 1.36 \\
\hline Jasenovac & 11 & 7.88 \\
\hline Greda Sunjska & 11 & 2.05 \\
\hline Lukavec & 9 & 1.46 \\
\hline Lonja & 7 & 3.62 \\
\hline Svinjičko & 6 & 1.83 \\
\hline Puska & 5 & 4.52 \\
\hline Drenov Bok & 4 & 2.9 \\
\hline Stružec & 3 & 6.54 \\
\hline Crkveni Bok & 3 & 3.27 \\
\hline Kratečko & 2 & 1.77 \\
\hline Ivanjski Bok & 1 & 3.40 \\
\hline Strmen & 1 & 2.34 \\
\hline Bistrač & 1 & 1.30 \\
\hline Graduša Posavska & 1 & 1.15 \\
\hline Krapje & 1 & 2.69 \\
\hline Košutarica & 1 & 2.44 \\
\hline Mlaka & 1 & 1.41 \\
\hline Suvoj & 1 & 0.9 \\
\hline Trebež & 0 & 0.4 \\
\hline
\end{tabular}


Dispersal distance was calculated from the location where the stork was hatched (and ringed) to the location where it was for the first time recorded to breed. For each individual, the direction was expressed in degrees calculated with geographic coordinates using www.movable-type.co.uk.

The probability that the number of nests and the size of the settlement had an influence on the dispersion was analysed by the Chi-square test, with Yates correction when $\mathrm{df}=1$, using the Statistica Software (STATSoft, Inc. 2004).

Circular statistics were applied to analyse the dispersal directions using Oriana software (Kovach Computing Services 2013). Oriana analyses orientation and other circular data, calculates various statistical tests for data measured in degrees or date and time. It further allows a graphical representation of data. Basic statistics were used to show the mean vector and mean vector deviation, the Rayleigh randomness test, and the Rao spacing test.

\section{RESULTS}

During fieldwork in 2015, a total of 101 active nests were surveyed, and 15 colour-ringed storks were recorded. Together with older data, it yielded a total of

Table 2. Locations of ringing and resightings, and the number of resightings per settlement in and outside the Lonjsko polje Nature Park.

Tablica 2. Lokacije prstenovanja i nalaza te broj uočenih prstenovanih jedinki u pojedinom naselju unutar i izvan Parka prirode Lonjsko polje.

\begin{tabular}{|c|c|c|c|c|c|c|c|c|}
\hline \multirow[b]{2}{*}{$\begin{array}{l}\text { LOCATION } \\
\text { OF RINGING }\end{array}$} & \multicolumn{7}{|c|}{ LOCATION OF RESIGHTING } & \multirow{2}{*}{$\frac{1}{5}$} \\
\hline & Čigoć & Mužilovčica & Osekovo & Bobovac & Jasenovac & Lonja & $\begin{array}{l}\text { Other } \\
\text { areas }\end{array}$ & \\
\hline Čigoć & 14 & 2 & 1 & 1 & & 1 & 2 & 21 \\
\hline Mužilovčica & 2 & 4 & & & & & & 6 \\
\hline Gušće & 2 & 1 & & & 1 & & 2 & 6 \\
\hline Bobovac & & & & & 1 & 1 & & 2 \\
\hline Greda Sunjska & 1 & & & & & & & 1 \\
\hline Kratečko & 1 & & & & & & & 1 \\
\hline Lonja & & 1 & & & & & & 1 \\
\hline Svinjičko & 1 & & 2 & & & & & 3 \\
\hline Crkveni Bok & 1 & & & & & 1 & & 2 \\
\hline Bistrač & 1 & & & & & & 1 & 2 \\
\hline Ivanjski Bok & & & & & & 1 & & 1 \\
\hline Strmen & 1 & & & & & & & 1 \\
\hline $\begin{array}{l}\text { Graduša } \\
\text { Posavska }\end{array}$ & & & & & & & 1 & 1 \\
\hline Lukavec & & & & & & & 1 & 1 \\
\hline TOTAL & 24 & 8 & 3 & 1 & 2 & 4 & 7 & 49 \\
\hline
\end{tabular}


92 records in the Archive of the Institute of Ornithology that refer to the resightings of the White Storks ringed in Lonjsko polje and its surroundings. Out of that, 49 (53.3\%) individual storks were observed breeding (Table 2) with a total of 63 resightings (excluding multiple resightings from the same nest in the same year); these records were later used in dispersal analyses.

\section{Natal and reproductive dispersion}

Out of 49 observed colour-ringed birds, 36.7\% individuals did not disperse outside the natal settlement. $63.3 \%$ dispersed, yet only 7 individuals $(14.3 \%)$ covered a distance longer than $50 \mathrm{~km}$ and were found breeding in Eastern Croatia, Hungary and Austria. The median was $4.21 \mathrm{~km}(\mathrm{IQR}=0-8.8, \mathrm{n}=49)$, with the shortest dispersal distance $2.1 \mathrm{~km}$ and the longest $454.3 \mathrm{~km}$ (Figure 1). Out of the total number of observed breeding birds within the studied area, only 10 individuals were observed during several successive years. The reproductive dispersion was observed in only one individual; the distance was $4.6 \mathrm{~km}$. The youngest stork observed breeding in the study area was in its $3^{\text {rd }}$ calendar year, while the oldest was in its $11^{\text {th }}$ calendar year.

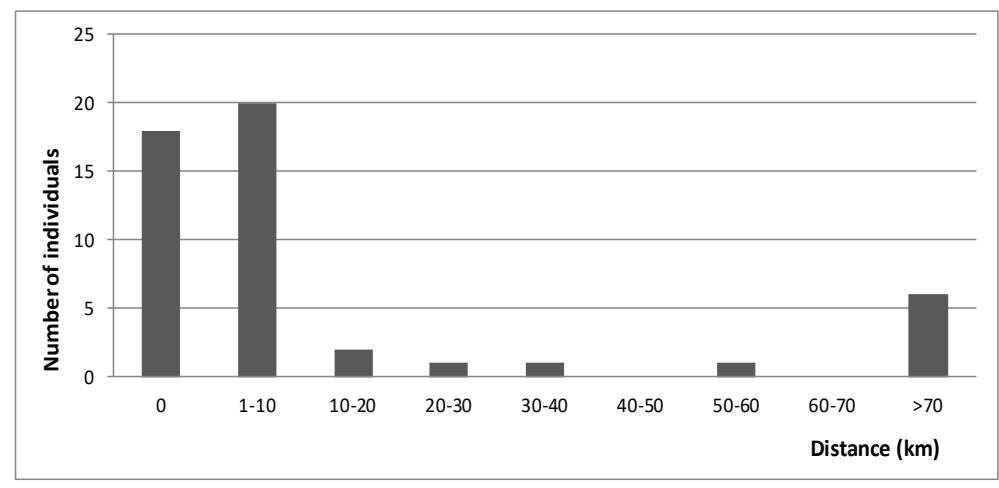

Figure 1. Distribution of natal dispersion distance according to the number of individuals ( $\mathrm{n}$ $=49$ ).

Slika 1. Distribucija udaljenosti natalne disperzije prema broju jedinki $(n=49)$.

\section{The number of nests in each settlement and the size of the settlement}

Almost a half of the individuals ringed in the area of Lonjsko polje and its surroundings were observed breeding in Čigoć (51\%). According to the data collected by fieldwork in 2015, Čigoć was the settlement with the largest number of nests (Table 1), while Graduša Posavska, Bistrač, Ivanjski Bok, Krapje, Suvoj, and Strmen had only one nest each. The largest settlement was Jasenovac, with the total length of $7.8 \mathrm{~km}$, and the smallest Suvoj, with $0.4 \mathrm{~km}$. The number of nests 
and the size of the settlement were not correlated (Pearson correlation $r=0.1924$, $p=0.475)$. The geographic arrangement of the settlements according to the number of nests and length are shown in Figure 2.

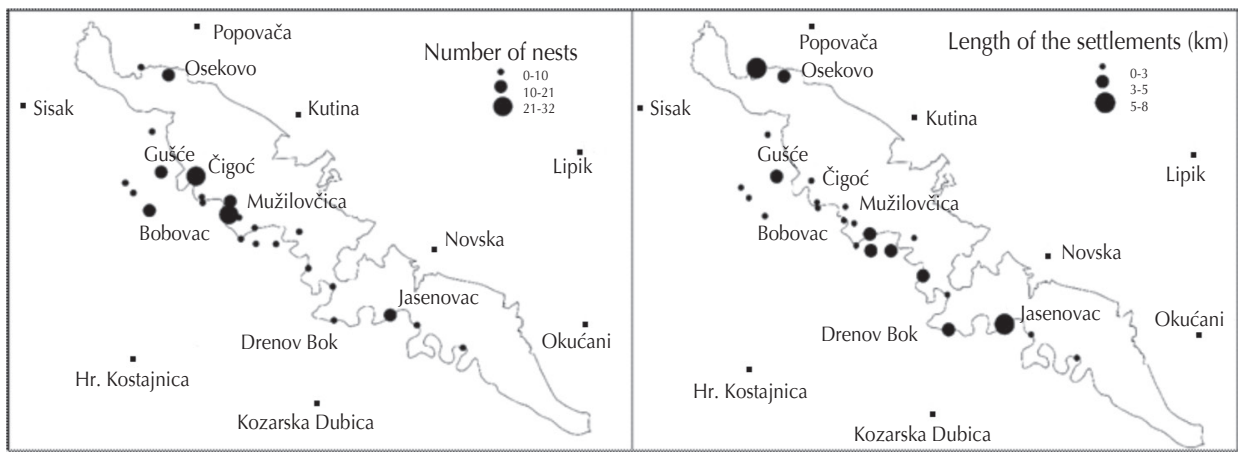

Figure 2. Geographical arrangement of researched settlements in Lonjsko polje and its surroundings, according to the number of nests (left) and the length of settlement (right).

Slika 2. Geografski položaj istraživanih naselja u Lonjskom polju i okolici te prikaz brojnosti gnijezda (lijevo) i dužine (desno) za pojedino naselje.

\section{The relation between natal dispersion and the number of nests in a particular settlement}

Data analysis has shown that most of the individuals from primary settlements either did not disperse (i.e., return to the natal settlement - distance $0 \mathrm{~km}$ ) or dispersed in surrounding settlements near the hatching area (up to $10 \mathrm{~km}$ ). Four individuals dispersed outside the research area (Figure 3, left). The median was $1.4 \mathrm{~km}(\mathrm{IQR}=0-6.9, \mathrm{n}=36$ ) with the shortest dispersal distance $2.8 \mathrm{~km}$, and the longest $424 \mathrm{~km}$. All storks hatched in secondary settlements dispersed (Figure 3, right). The median was $7.5 \mathrm{~km}(\mathrm{IQR}=3.5-10.4, \mathrm{n}=13)$ with the shortest dispersal distance $2.2 \mathrm{~km}$, and the longest $454.3 \mathrm{~km}$.
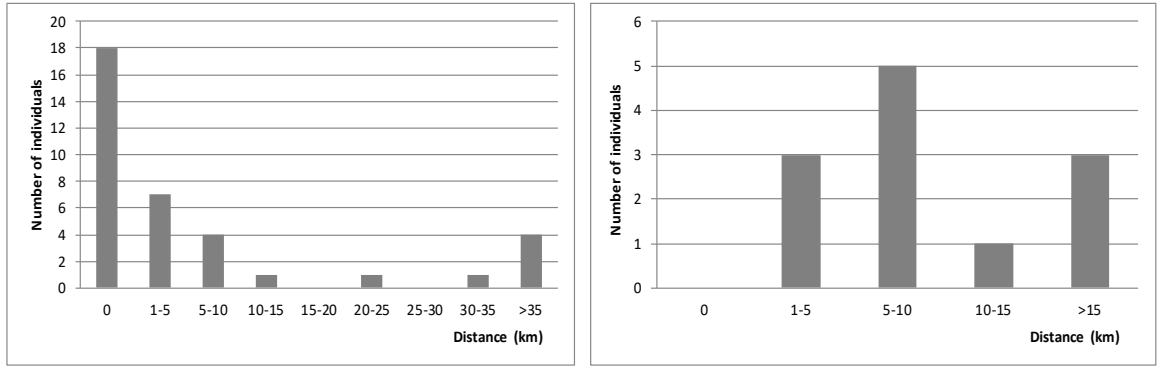

Figure 3. Distribution of the distances of the natal dispersion for the individuals dispersed from the primary ( $n=36$, left) and the secondary settlements $(n=13$, right).

Slika 3. Distribucija udaljenosti natalne disperzije za jedinke koje su disperzirale iz primarnih ( $n=36$, lijevo) i sekundarnih naselja $(n=13$, desno). 
The assumption that individuals disperse from the secondary towards the primary settlement has been tested by the Chi-square test (with Yates's correction). The null hypothesis was that the number of nests had no influence on dispersion, therefore the dispersion was random and the individuals had equal probability to disperse towards the secondary or the primary settlement. Only individuals that dispersed outside natal settlement were analysed, $n=24$. The null hypothesis was rejected, since the results have shown significant difference with four times more birds dispersing from the secondary to the primary settlement $\left(X^{2}=\right.$ 4.59, $\mathrm{p}=0.032, \mathrm{df}=1$ ) (Figure 4).

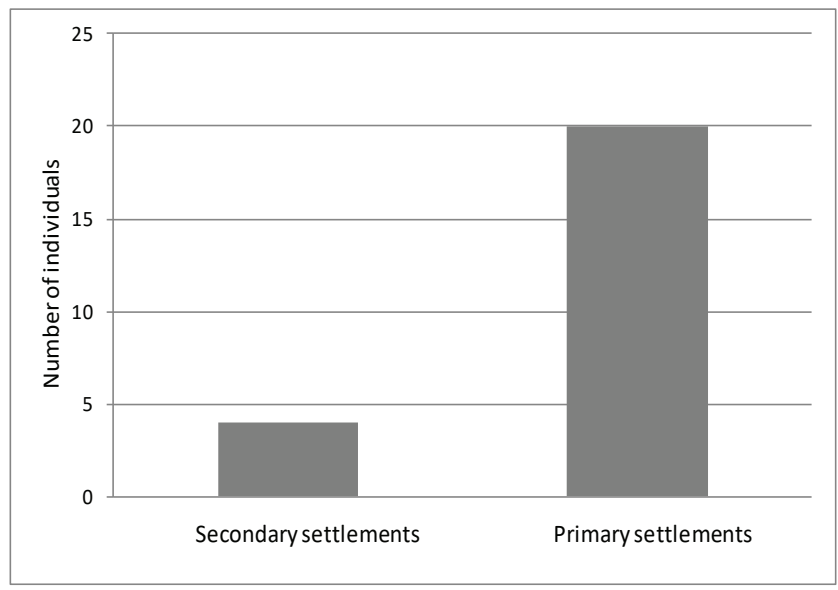

Figure 4. Number of individuals that dispersed to the secondary and the primary settlement $(\mathrm{n}=24)$.

Slika 4. Broj jedinki koje su disperzirale u sekundarna i primarna naselja $(n=24)$.

\section{The relation of natal dispersal and the size of the settlement}

All the observed White Storks from large settlements dispersed, yet 6 out of 9 birds moved less than $10 \mathrm{~km}$ from the hatching settlement (Figure 5, left). The median was $7.2 \mathrm{~km}(\mathrm{IQR}=4.2-31.4, \mathrm{n}=9)$. The largest distance between the hatching and the breeding location was $424 \mathrm{~km}$, while the lowest was $2.8 \mathrm{~km}$. Out of 40 storks that hatched in small settlements, 18 birds (45\%) did not disperse outside the natal settlement (Figure 5, right). For birds that had dispersed, the median was $2.9 \mathrm{~km}(\mathrm{IQR}=0-8.6, \mathrm{n}=40)$. The lowest dispersion distance was $2.1 \mathrm{~km}$, while the largest was $454.3 \mathrm{~km}$. The assumption about the connection between the dispersion and the size of the settlement was tested by the Chi-square test with Yates's correction. The null hypothesis was that the length of settlement does not affect the stork dispersal, so individuals have an equal probability of dispersing to each settlement regardless of its size. Only dispersed individuals were analysed, $n=24$. The storks dispersed independently of the size of the set- 
tlement and observed results did not differ significantly from the expected $\left(\mathrm{X}^{2}=\right.$ $0.34, \mathrm{p}=0.561, \mathrm{df}=1)$, thus null hypothesis was accepted.
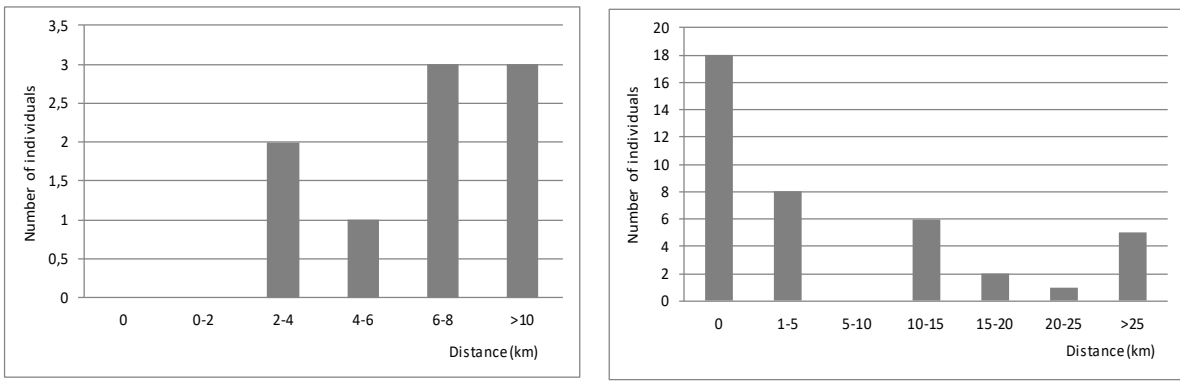

Figure 5. Distribution of natal dispersion distance for individuals dispersed from large settlements ( $n=9$, left) and small settlements ( $n=40$, right).

Slika 5. Raspodjela udaljenosti natalne disperzije za jedinke koje su disperziraju iz veliki naselja $(n=9$, lijevo) i malih naselja $(n=40$, desno).

\section{The direction of dispersed individuals}

A circular analysis of the direction of individuals dispersed within the Lonjsko polje indicates that the direction was not random, Rayleigh's test $=3.42, \mathrm{P}$ $<0.05$, Rao's Spacing test $=194.82, \mathrm{P}<0.05, \mathrm{n}=24$ (Figure 6). The mean vector was $64.5^{\circ}, \pm \mathrm{SD} 79.98^{\circ}$. Birds tended to disperse to the northwest and southeast, and to a lesser extent to the northeast. The direction analysis is shown for all settlements where individuals dispersed (Figure 7).

Figure 6. Direction of natal dispersion, $\mathrm{n}=24$.

Slika 6. Smjer natalne disperzije, $n=24$.

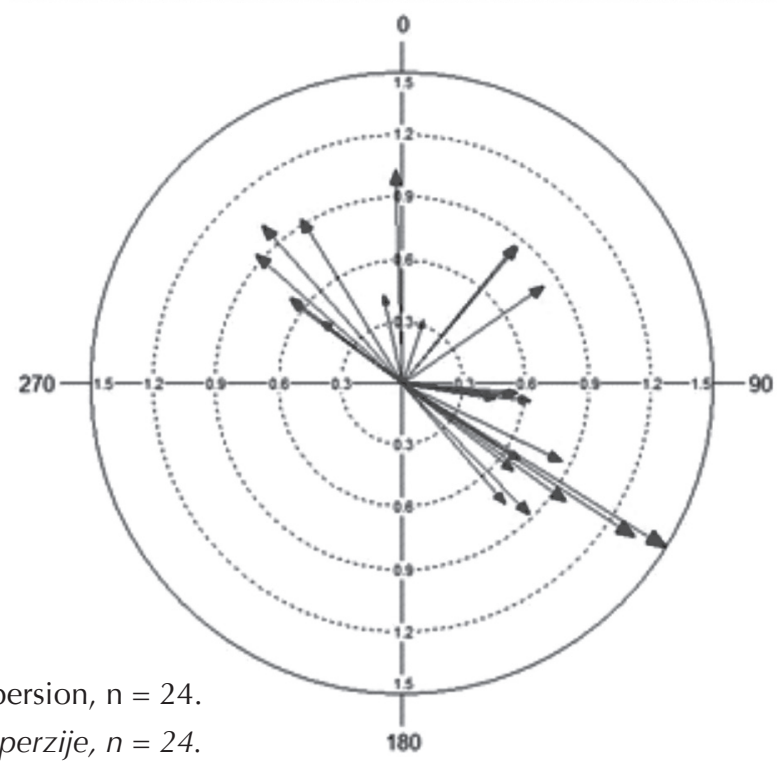




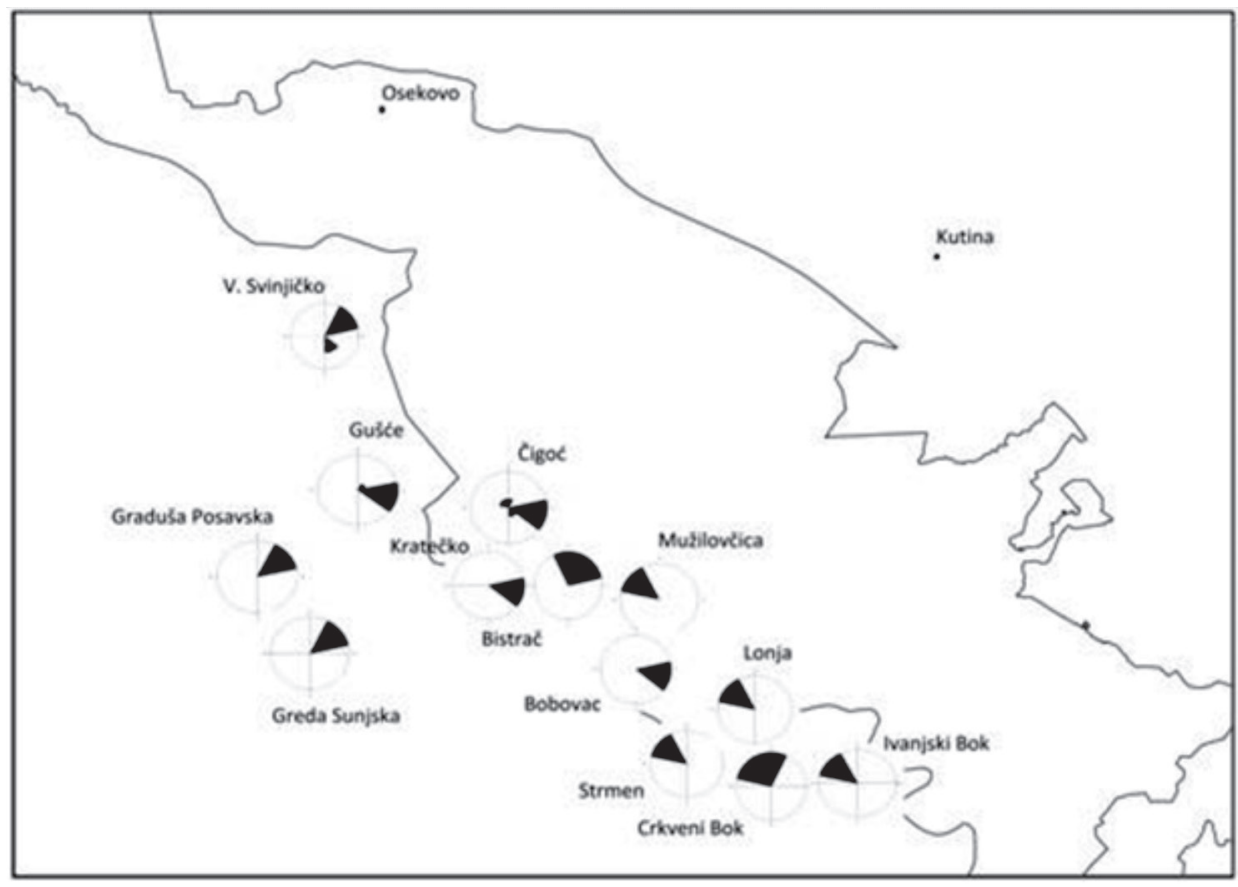

Figure 7. Dispersion directions for each settlement in Lonjsko polje and nearby surroundings, from which the individuals dispersed.

Slika 7. Smjerovi disperzije za pojedina naselja u Lonjskom polju i okolici iz kojeg su jedinke disperzirale.

\section{DISCUSSION}

The results showed that the majority of the observed individuals returned to the Lonjsko polje and the surrounding area for breeding and that more than a third of them were found in their natal settlement. Only $14.3 \%$ of White Storks dispersed at a distance longer than $50 \mathrm{~km}$. Intensive observations of colourringed birds in the Nature Park Lonjsko polje compared with unsystematic observations outside this area might result in an overrepresentation of birds that did not disperse from the Nature Park area. The actual natal dispersal is probably larger than the one recorded here, as the resighting probability gradually decreases with the distance from the area of intensive activity of ringers (KANIA 2006). However, our results are in accordance with other studies based on ringing recoveries: KANIA (2006) found that $83 \%$ of first nesting attempts were noted up to $30 \mathrm{~km}$ from the natal place, while HANCock et al. (1992) stated that 80\% of first breeders settle within $50 \mathrm{~km}$ from the hatching site. Such high degree of philopatry was also observed in other species such as Spoonbill Platalea leucorodia and Black-legged Kittiwake Rissa tridactyla (Coulson \& Mévergnies 1992, CourT \& Aguilera 1997, Winkler et al. 2004). The study of natal dispersal in south- 
ern Poland covering $7000 \mathrm{~km}^{2}$ resulted with median dispersal distance of $26 \mathrm{~km}$ (Chernetsov 2006), where higher values might be the result of less frequent colonial breeding in Poland, but also of the greater study area.

From the total number of birds observed during several successive years, the majority (90\%) were observed breeding in the same settlement over several years, while only one individual showed reproductive dispersion (10\%). Similarly, very high nest fidelity was observed both in Polish and in Spanish White Stork populations. In Spain, about $80 \%$ of the examined individuals were faithful to their previous nests (Vergara et al. 2006), while Chernetsov (2006) in a study of 73 individuals found only two cases with distances $<10 \mathrm{~km}$. Fidelity to the nesting site is considered a useful strategy that has been observed in other species in the family of Ciconiiformes, Anseriformes and Procellariiformes (Vergara et al. 2006). The distance of reproductive dispersion in this study was $4.6 \mathrm{~km}$, which is close to main natal dispersion in this study $(4.21 \mathrm{~km})$. Results from other research have also shown that natal dispersion is more common and individuals travel larger distances when compared to reproductive dispersion (Vergara et al. 2006, Hénaux et al. 2007, Itonaga 2009).

The results have shown that the storks dispersed mainly from the secondary to the primary settlements, while the correlation with the size of the settlement (or the number of potentially available nesting sites) was not confirmed. Due to the obtained correlation of the dispersion and the number of nests in a particular settlement, it may be concluded that the individuals are socially attracted to other breeding pairs and that they use other individuals as indicators of a good nesting habitat. It has been observed that some colonial species decide whether to nest in the natal colony or to disperse into another based depending on the reproductive success of other breeding pairs (HÉnAux et al. 2007). Although generally younger storks spend their second summer at wintering grounds, it is possible that some individuals leave the wintering place before they enter the reproductive phase of life (first breeding is most common in the fourth year) and visit locations where breeding populations exist (Cramp \& Simmons 1977, Itonaga 2009). In order to be able to scientifically confirm this behaviour, further research is needed.

The analyses have shown that researched individuals have a tendency to move towards northwest and southeast directions. This was expected due to the geographical position of settlements in Lonjsko polje along the Sava River, and because of the dispersion to the primary settlement. The study area is situated in the southwest part of the Pannonian basin, while the main feeding and breeding habitats are situated towards the north and the northeast. At a smaller scale, the direction of dispersal of storks from individual settlements was towards the settlements with the highest number of nests (Čigoć and Mužilovčica).

This study was the first research of natal dispersal of the White Stork in Croatia. It confirmed the high philopatry of this species and showed that dispersal is 
more influenced by the social attraction of conspecifics than by space available for nesting. Although most of the birds returned to breed in Lonjsko polje, some of them moved to Eastern Croatia, Hungary and Austria, confirming gene flow between populations in the Pannonian basin.

\section{Acknowledgements}

We would like to thank ringers who participated in White Stork ringing in Lonjsko polje Nature Park, but also in other part of Croatia: V. Bartovsky, L. Basrek, D. Gatolin, D. Grlica, P. Grljević, J. Horvat, Z. Horvat, L. Jurinović, D. Leiner, K. Leskovar, T. Mikuska, J. Mužinić, A. Radalj, D. Radović, I. Sever, M. \& N. Šetina, Z. Tadić, and all people who observed and report ringed storks. We thank to the Public Institution of the Lonjsko Polje Nature Park for enabling this study. We are grateful to reviewers for their constructive comments.

\section{References}

Barbraud, C., Barbraud, J-C., Barbraud, M. (1999): Population dynamics of the White StorkCiconia ciconia in western France. Ibis 141: 469-479.

Berthold, P. (2001): Bird migration. Oxford University Press, 272 pp.

Bowler, D. E., Benton, T. G. (2005): Causes and consequences of animal dispersal strategies: relating individual behavior to spatial dynamics. Biological Reviews of the Cambridge Philosophical Society 80: 205-225.

Chozas, P. (1984): Situacion de la poblacion de la Ciguena blanca, Ciconia ciconia, en Espana segun los ultimos censos nacionales (1979 y 1981). Boletin de la Estacion Central de Ecologia 13: 29-48.

Coulson, J.C., Mévergnies, N. (1992): Where do young kittiwakes Rissa tridactyla breed, philopatry or dispersal? Ardea 80: 187-197.

Court, C., Aguilera, E. (1997): Dispersal and migration in Eurasian Spoonbills Platalea leucorodia. Ardea 85: 193-202.

Cramp, S., Simmons, K. E. L. (1977): The birds of the Western Palearctic. Vol 1. Oxford University Press.

Cuadrado, M., Sánchez, Í., Barcello, M., Armario, M. (2016): Reproductive data and analysis of recoveries in a population of white stork, Ciconia ciconia, in southern Spain: a 24-year study. Animal Biodiversity and Conservation 39: 37-44.

Forero, M. G., Donázar, J. A., Hiraldo, F. (2002): Causes and fitness consequences of natal dispersal in a population of black kites. Ecology 83: 858-872.

Goriup P., Schulz H. (1990): Conservation management of the White Stork: an international opportunity. Cambridge, United Kindom, ICBP Study Report No. 37.

Greenwood, P. J. (1980): Mating systems, philopatry and dispersal in birds and mammals. Animal Behaviour 28: 1140-1162. 
Greenwood, P. J., Harvey, P. H. (1982): The natal and breeding dispersal of birds. Annual Review of Ecology, Evolution, and Systematics 13: 1-21.

Gugić G., Hima V., Posavec Z., Bogović E., Ivaštinović D. (2011): Park prirode Lonjsko polje živući krajobraz i poplavni ekosustav srednje Posavine. Plan upravljanja. Javna ustanova Parka prirode Lonjsko polje 178 pp.

Hancock, J. A., Kushlan, J. A., Kahl, M. P. (1992): Storks, ibises and spoonbills of the world. Academic Press, London.

Hénaux, V., Bregnbolle, T., Lebreton, J.D. (2007): Dispersal and recruitment during population growth in a colonial bird, the great cormorant Phalacrocorax carbo sinensis. Journal of Avian Biology 38: 44-57.

Itonaga, N. (2009): White stork (Ciconia ciconia) of Eastern Germany: age-dependent effects on dispersal behaviour. Dissertation, $68 \mathrm{pp}$.

Kania, W. (2006): Movements of Polish White Storks Ciconia ciconia - an analysis of ringing results. in: W: Tryjanowski P., Sparks T.H., Jerzak L. (eds.). The White Stork in Poland: studies in biology, ecology and conservation. Bogucki Wyd. Nauk., Poznań: 249-294.

Kovach Computing Services. (2013): Oriana version 3.21.Pentraeth, U.K.

Kralj, J., Barišıć, S., Tutiš, V., ĆıKović, D. (2013): Atlas selidbe ptica Hrvatske. Hrvatska akademija znanosti i umjetnosti. Zagreb, $230 \mathrm{pp}$.

Paradis, E., Baillie, S. R., Sutherland, W. J., Gregory, R. D. (1998): Patterns of natal and breeding dispersal in birds. Journal of Animal Ecology 67: 518-536.

Perennou, C., Sadoul, N., Pineau, O., Johnson, E. R., Hafner, H., (1996): Management of nest sites for colonial waterbirds. Conservation of Mediterranean Wetlands - number 4. Tour du Valat, Arles, France, 114 pp.

Serrano, D., Oro, D., Ursúa, E., Tella, J. L. (2005): Colony size selection determines adult survival and dispersal preferences: Allee effects in a colonial bird. The American naturalist 166: 22-31.

StAтSoft, Inc. (2004). Statistica (data analysis software system), version 7. www.statsoft. com.

Sutherland, G. D., Harestad, A. S., Price, K., Lertzman, K. P. (2000): Scaling of natal distances in terrestrial birds and mammals. Conservation Ecology 4 (1): 16.

Vergara, P, Aguirre, J. I., Fargello, J. A., Dávila, J. A. (2006): Nest - site fidelity and breeding success in White stork Ciconia ciconia. Ibis 148: 672-677.

Winkler, D.W., Wrege, W.P., Allen, P.E., Kast, T.L., Senesac, P., Wasson, M.F., Llambías, P.E., Ferretti, V., Sullivan, P.J. (2004): Breeding dispersal and philopatry in the tree swallow. The Condor 106: 768-776. 


\section{SAŽETAK}

Postoje dva tipa disperzije: natalna i reproduktivna. Natalna disperzija je češća i jedinke prelaze puno veće udaljenosti nego tijekom reprodukcijske disperzije. Smjer i udaljenost na kojoj jedinka disperzira ovisi o gustoći populacije, kvaliteti staništa, spolu, vjerojatnosti parenja u srodstvu ili dominantnosti drugih jedinki. Jedinke mnogih vrsta su vjerne mjestu gniježđenja, stoga reproduktivna disperzija nije česta i najčešće se odvija nakon slabog reprodukcijskog uspjeha ili gubitka partnera. Roda je ptica selica i redovita gnjezdarica u Hrvatskoj. Istraživana je disperzija bijele rode Ciconia ciconia u Parku prirode Lonjsko polje. Analizom nalaza roda označenih prstenovima u boji, utvrđena je koliko je zastupljena natalna disperzija u odnosu na reproduktivnu te postoji li utjecaj brojnosti gnijezda u naseljima te veličine naselja na udaljenost i smjer disperzije. 36,7\% jedinki nije disperziralo izvan naselja u kojem se izleglo, dok je samo 14,3\% prešlo udaljenosti veće od $50 \mathrm{~km}$. Te su ptice nađene $\mathrm{u}$ istočnoj Hrvatskoj, Austriji i Mađarskoj. Srednja udaljenost disperzije bila je 4,21 km (IQR $=0-8,8, \mathrm{n}=49)$. Rezultati su pokazali da rode natalnom disperzijom odlaze iz naselja s malim u naselja s velikim brojem gnijezda što indicira da su socijalno privučene drugim jedinkama te da disperzija ne ovisi o veličini naselja (odnosno raspoloživom prostoru za gniježđenje). 